Repository of the Max Delbrück Center for Molecular Medicine (MDC) Berlin (Germany)

http://edoc.molc-berlin.de/8301/

\title{
Uptake, Biodistribution, and Time Course of Naked Plasmid DNA Trafficking After Intratumoral In Vivo Jet Injection
}

Dr. W. Walther, T. Minow, R. Martin, I. Fichtner, P.M. Schlag, U. Stein

This is a copy of an article published in the "Human Gene Therapy" (C) 2006 copyright Mary Ann Liebert, Inc.; "Human Gene Therapy" is available online at: http://online.liebertpub.com. 


\title{
Uptake, Biodistribution, and Time Course of Naked Plasmid DNA Trafficking After Intratumoral In Vivo Jet Injection
}

\author{
W. WALTHER,${ }^{1}$ T. MINOW, ${ }^{2}$ R. MARTIN,${ }^{1}$ I. FICHTNER,${ }^{1}$ P.M. SCHLAG,${ }^{2}$ and U. STEIN ${ }^{1}$
}

\begin{abstract}
Nonviral jet injection is an applicable technology for in vivo gene transfer of naked DNA. However, little is known about the biodistribution and clearance of jet-injected DNA, or about its localization within tissue and cells. Therefore, in this study we analyzed the intratumoral and systemic biodistribution of jet-injected naked DNA in human colon carcinoma-bearing NCr-nu/nu mice, which were jet-injected with the pCMV $\beta$ plasmid DNA. Intratumoral and systemic plasmid DNA biodistribution was analyzed 5, 10, 20, and 40 min and 3, 6, 24, 48, and $72 \mathrm{hr}$ after jet injection, using quantitative real-time polymerase chain reaction. In the tumors, a rapid drop in naked DNA load within $24 \mathrm{hr}$ of jet injection was shown. Detailed analysis of intratumoral distribution of rhodamine-labeled DNA revealed the presence of plasmid DNA within tumor cells 5 min after jet injection and further accumulation of significant DNA amounts in the cell nuclei 30 to 60 min after jet injection. In the blood, DNA amounts rapidly dropped within 10 to $40 \mathrm{~min}$ of jet injection to less than $0.001 \mathrm{pg}$ of plasmid per $250 \mathrm{ng}$ of tissue DNA and only minimal plasmid DNA dissemination was detected in liver, lung, spleen, kidney, and ovaries, which was cleared 3 to 6 hr after jet injection. By contrast, in heart, bone marrow, and brain almost no plasmid DNA was detectable.
\end{abstract}

\section{OVERVIEW SUMMARY}

In this study jet injection was used for the direct gene transfer of naked DNA into tumors to evaluate the biodistribution of plasmid DNA. The intratumoral plasmid DNA load and the systemic appearance of the DNA was analyzed by quantitative real-time polymerase chain reaction 5, 10, 20, and $40 \mathrm{~min}$ and $3,6,24,48$, and $72 \mathrm{hr}$ after jet injection. The results indicated a rapid decrease in plasmid DNA concentration in the tumors. Jet injection of rhodamine-labeled DNA revealed that as early as 5 min after in vivo jet injection plasmid DNA appears in the cytoplasm and in the nuclei of tumor cells, indicating the rapid intracellular and nuclear entry of jet-injected plasmid DNA. Regarding systemic biodistribution, the highest amounts of plasmid DNA were detected in the blood 5 min after intratumoral jet injection, and rapidly dropped within 10 to $40 \mathrm{~min}$. By comparison, only minimal amounts of plasmid DNA were detected in peripheral organs, which were cleared within 3 to $6 \mathrm{hr}$.

\section{INTRODUCTION}

N GENE THERAPY, including cancer gene therapy, the major-
ity of delivery systems employed are of retroviral or adeno-
viral origin (Walther and Stein, 2000). Because viral vectors
have different disadvantages, such as provocation of unwanted
immune responses, virus-associated toxicities, viral recombi-
nation, or insertional mutagenesis, many investigators have
shifted their attention toward nonviral transfer systems, espe-
cially if timely restricted expression of the transgene is at-
tempted (Niidome and Huang, 2002). The use of naked DNA
is particularly attractive, because of its low immunogenicity,
minimal or absent toxicity and its simplicity of use. Besides the
simple needle and syringe injection, most applications of naked
DNA are associated with the employment of physical transfer
technologies for the introduction of naked DNA into the tar-
geted tissue. Such physical technologies include in vivo elec-
troporation, focused ultrasound, particle bombardment (biolis-
tic transfer), or jet injection (Li and Huang, 2000; Somiari et
al., 2000; Niidome and Huang, 2002). Some of these tech-

\footnotetext{
${ }^{1}$ Max Delbrück Center for Molecular Medicine, 13092 Berlin, Germany.

${ }^{2}$ Robert Rössle Clinic, Charité, 13125 Berlin, Germany.
} 
nologies have entered the level of clinical testing in gene therapy protocols.

We and others have demonstrated that efficient gene transfer of naked DNA into tumors can be achieved in vivo, if jet injection technology is used (Walther et al., 2001). Jet injection-mediated intratumoral gene transfer of reporter gene-expressing plasmids or therapeutic gene-expressing constructs led to the expression of these genes in various tumor models, using only small amounts of naked DNA (Walther et al., 2001, 2002). Similar results have been reported when muscle tissue was targeted for jet injection gene transfer (Furth et al., 1992, 1995; Cartier et al., 2000).

Apart from the fact that jet injection gene transfer is effective for introducing naked DNA into tumors in vivo, there is a need to analyze and understand the fate of naked DNA applied to tumors. There are various reports dealing with the biodistribution of transduced naked DNA after needle injection, in vivo electrotransfer, or biolistic transfer (Dupuis et al., 2000; Pilling et al., 2002; Cappelletti et al., 2003). However, nothing is known about the fate of naked DNA in vivo if applied by jet injection. We therefore analyzed the time-dependent biodistribution of jet-injected plasmid DNA in tumors and the systemic dissemination of naked DNA, using quantitative real-time polymerase chain reaction (PCR). This type of real-time PCR is a sensitive method allowing quantitative detection of small amounts of plasmid DNA jet-injected into tumors or of plasmid disseminated to the blood circulation or to other organs. Several reports have demonstrated the usefulness of this method for biodistribution studies of naked DNA gene transfer (Hackett et al., 2000; Maruyama et al., 2002; Rose et al., 2002). In addition, we employed quantitative real-time reverse transcription (RT)-PCR to analyze reporter gene mRNA expression in jet-injected tumors and to evaluate the potential transcriptional activity of disseminated plasmid in other organs.

We further analyzed the path taken by plasmid DNA within the cells of jet-injected tumors to localize cellular distribution in more detail by confocal fluorescence microscopy. Using this approach, we were able to provide more insight into the localization of jet-injected naked DNA at the tissue and cellular levels during the time course of intratumoral DNA clearance.

\section{MATERIAL AND METHODS}

\section{Preparation of plasmid DNA}

The $\mathrm{pCMV} \beta$ plasmid (Clontech, Palo Alto, CA) was used for expression of the bacterial $\beta$-galactosidase gene (lacZ). The plasmid was amplified in One Shot competent Escherichia coli bacteria (Invitrogen, Groningen, The Netherlands), purified with a JETSTAR purification kit (GENOMED, Löhne, Germany), and dissolved in phosphate buffer (150 $\mathrm{mM}$ $\mathrm{Na}_{2} \mathrm{HPO}_{4} / \mathrm{NaH}_{2} \mathrm{PO}_{4} ; \mathrm{pH}$ 7.0) to a final concentration of $1 \mu \mathrm{g}$ of DNA per microliter. This plasmid DNA was used for intratumoral in vivo jet injection.

To study the tissue and intracellular localization of plasmid DNA after jet injection, the rhodamine-labeled pGeneGRIP plasmid (Gene Therapy Systems, San Diego, CA) was used.

\section{Intratumoral in vivo jet injection of naked $p C M V \beta$ plasmid DNA}

For the nonviral in vivo gene transfer, female NCr-nu/nu mice xenotransplanted with patient-derived human colon carcinoma Colon5737 cells were used (Fichtner et al., 2004). When tumors reached a size of approximately $6 \times 6 \mathrm{~mm}$ the tumor-bearing animals were anesthetized and received five intratumoral jet injections of $\mathrm{pCMV} \beta$ plasmid DNA through the skin, using a Swiss Injector prototype (Electro Medical Systems, Nyon, Switzerland) at a pressure of $3.0 \mathrm{bar}$, a condition optimized in previous studies for in vivo gene transfer (Walther et al., 2002). These jet injections were applied at five different sites in the tumor (see Fig. 4B). The respective control animals were jet-injected with saline. Each jet injection applied $10 \mu \mathrm{l}$ of plasmid solution containing naked plasmid DNA at $1 \mu \mathrm{g} / \mu \mathrm{l}$. Therefore, each animal received a total dose of $50 \mu \mathrm{g}$ of $\mathrm{pCMV} \beta$ plasmid DNA. Five, 10, 20, and $40 \mathrm{~min}$ and 3, 6, 24, 48, and $72 \mathrm{hr}$ after jet injection, animals ( $n=3$ per time point) were killed and tumors were removed and snap frozen in liquid nitrogen for further analysis. Furthermore, whole blood, liver, lung, heart, bone marrow, spleen, kidney, ovaries, and brain were removed and shock frozen in liquid nitrogen for further analysis.

For intratumoral and cellular localization of rhodamine-labeled plasmid DNA, animals received five jet injections of pGeneGRIP plasmid-containing solution. The animals were killed 5, 30, and $60 \min (n=2$ animals per time point) after jet injection, and tumors were removed and shock frozen for further analysis.

\section{Quantitative real-time PCR analysis of $p C M V \beta$ plasmid DNA distribution in jet-injected animals}

For detection of $\mathrm{pCMV} \beta$ plasmid DNA, cellular DNA was isolated from serial cryosections $(20 \mu \mathrm{m})$ of tumors and the respective organs, using a QIAamp DNA mini kit (Qiagen, Valencia, CA).

Each quantitative real-time PCR $\left(95^{\circ} \mathrm{C}\right.$ for $30 \mathrm{sec}$; 45 cycles of $95^{\circ} \mathrm{C}$ for $10 \mathrm{sec}, 62^{\circ} \mathrm{C}$ for $10 \mathrm{sec}$, and $72^{\circ} \mathrm{C}$ for $10 \mathrm{sec}$ ) was performed with $250 \mathrm{ng}$ of cellular DNA in a LightCycler reaction (LightCycler DNA master hybridization probes kit; Roche Diagnostics, Mannheim, Germany) in duplicate per sample. For the $\mathrm{pCMV} \beta$ plasmid a 127-bp amplicon (forward primer, 5' AAGCAAAAAAGAAGTCACCATG-3'; fluorescein isothiocyanate [FITC]-labeled probe, 5'-CGGTCTGGGAGGCATTGGT-3'-FITC; LCRed640-labeled probe, LCRed640-5'-GGACACCAGCAAGGAGCTGCT-3' ; reverse primer, 5' -GTAAAACGACGGGATCGC-3') was produced, which was detected by the gene-specific fluorescein- and LCRed640-labeled hybridization probes (syntheses of primers for $\mathrm{pCMV} \beta$ : BioTeZ, Berlin, Germany; syntheses of probes for lacZ: TIB MOLBIOL, Berlin, Germany) (Fig. 1A).

$\operatorname{pCMV} \beta$ concentrations in $250 \mathrm{ng}$ of cellular DNA were calculated by comparison with a "spiked" standard curve of $\mathrm{pCMV} \beta$ plasmid. For spiking, $\mathrm{pCMV} \beta$ plasmid DNA was serially diluted $(0.005,0.05,0.5,5,10,30,50$, and $80 \mathrm{ng}$ in duplicate) in $250 \mathrm{ng}$ of cellular DNA isolated from the human colon carcinoma cell line SW480 or from the organs of test animals.

Each organ-based spiked standard curve was generated in parallel in each real-time PCR run (Fig. 2A-C) to ensure the accuracy of DNA quantitation. The quality of PCR products 


\section{primer and probe position for real-time PCR}

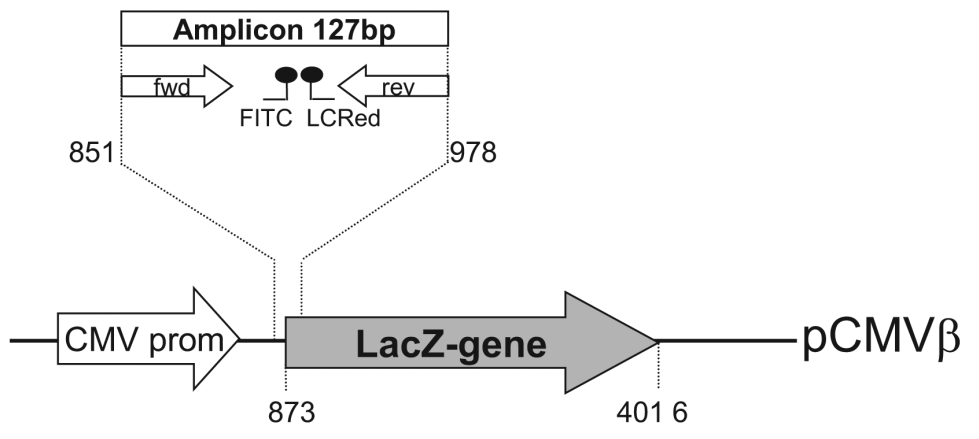

FIG. 1. Schematic representation of primer and probe positions for quantitative real-time PCR (top) and real-time RT-PCR (bottom). For the PCR the forward primers bind to sequences of the $\mathrm{pCMV} \beta$ plasmid backbone located 5' upstream from the ATG of the lac $Z$ gene to ensure plasmid specificity of the PCR analysis of plasmid distribution in the tumor and in the organs of jet-injected animals. The real-time PCR creates an amplicon of $127 \mathrm{bp}$. For the real-time RT-PCR the primers are designed to bind within the cDNA sequence derived from the LacZ mRNA, which leads to an amplicon of $101 \mathrm{bp}$. CMV prom, cytomegalovirus promoter; LacZ, $\beta$-galactosidase gene; fwd, forward primer; rev, reverse primer; FITC, FITC-labeled probes; LCRed, LCRed640-labeled probes.

\section{primer and probe position for real-time RT-PCR}

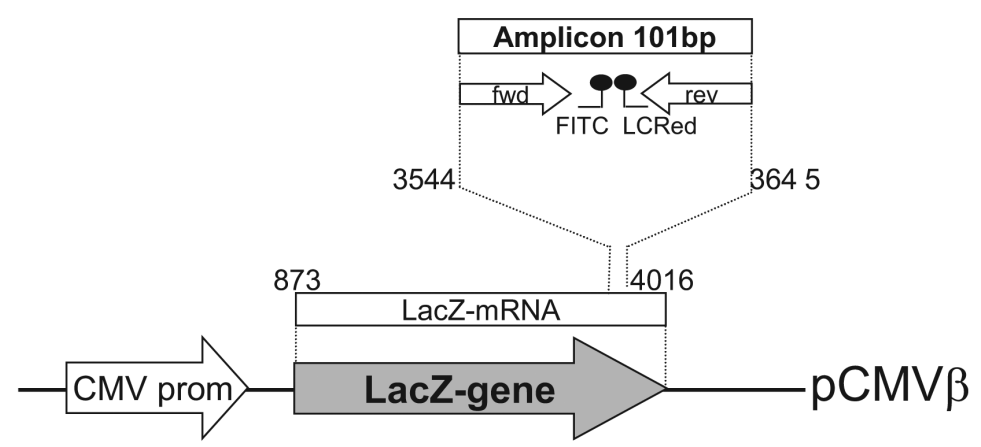

was evaluated for each run by the corresponding melting curves as shown in Fig. 2E.

\section{Quantitative real-time $R T-P C R$ analysis of $L a c Z$ expression in jet-injected tumors}

Total RNA from cryosections of tumors or organs was isolated by the TRIzol method according to the manufacturer's instructions (Life Technologies, Karlsruhe, Germany). To prevent potential contamination with plasmid DNA, all RNA probes were treated with RNase-free DNase I (Roche Diagnostics). The reverse transcriptase (RT) reaction was performed with $30 \mathrm{ng}$ of total RNA isolated from tumor tissues or respective organs (murine leukemia virus [MuLV] reverse transcriptase; PerkinElmer, Weiterstadt, Germany).

Quantitative real-time PCR $\left(95^{\circ} \mathrm{C}\right.$ for $30 \mathrm{sec}$; 45 cycles of $95^{\circ} \mathrm{C}$ for $10 \mathrm{sec}, 62^{\circ} \mathrm{C}$ for $10 \mathrm{sec}$, and $72^{\circ} \mathrm{C}$ for $10 \mathrm{sec}$ ) was done with the LightCycler (LightCycler DNA master hybridization probes kit; Roche Diagnostics). Expression of the lacZ gene was determined in duplicate for each sample. For lacZ a 101-bp amplicon (forward primer, 5'-CCGTTGATGTTGAAGTGG-3'; FITC-labeled probe, 5'-GCGCGGATTGGCCTGAACT-3'FITC; LCRed640-labeled probe, LCRed640-5'-CAGCTGGCGCAGGTAGCAGA-3'; reverse primer, 5'-CTAATCC-
GAGCCAGTTTACCC-3') was produced,which was detected by gene-specific fluorescein- and LCRed640-labeled hybridization probes (syntheses of primers for lacZ: BioTeZ; syntheses of probes for lacZ: TIB MOLBIOL) (Fig. 1B).

Calibrator cDNA derived from a stably $\mathrm{pCMV} \beta$-transduced LacZ-expressing cell clone (human colon carcinoma cell line SW480) was employed in serial dilutions $(3,10,30,100,300$, and $500 \mathrm{ng}$ in duplicate) simultaneously in each run and served as internal standard for LacZ calculations. LacZ expression (mean of the duplicates) for each tumor sample was calculated and expressed as relative fold LacZ mRNA expression in relation to the calibrator cell line. For all RT-PCR runs the quality of corresponding PCR products was evaluated on the basis of melting curves.

\section{Isolation of nuclear DNA from jet-injected tumor tissues}

For the isolation of nuclei from jet-injected tumor tissues, tumors were cryosectioned $(20 \mu \mathrm{m})$ and 10 to 20 sections were collected in an Eppendorf tube. The sections were homogenized in $1 \mathrm{ml}$ of lysis buffer (40 $\mathrm{m} M$ sodium citrate, $1 \%$ Triton $\mathrm{X}-100)$ on ice. After a 5-min incubation on ice the supernatant was transferred to another tube and centrifuged at $1000 \mathrm{rpm}$ for 
A

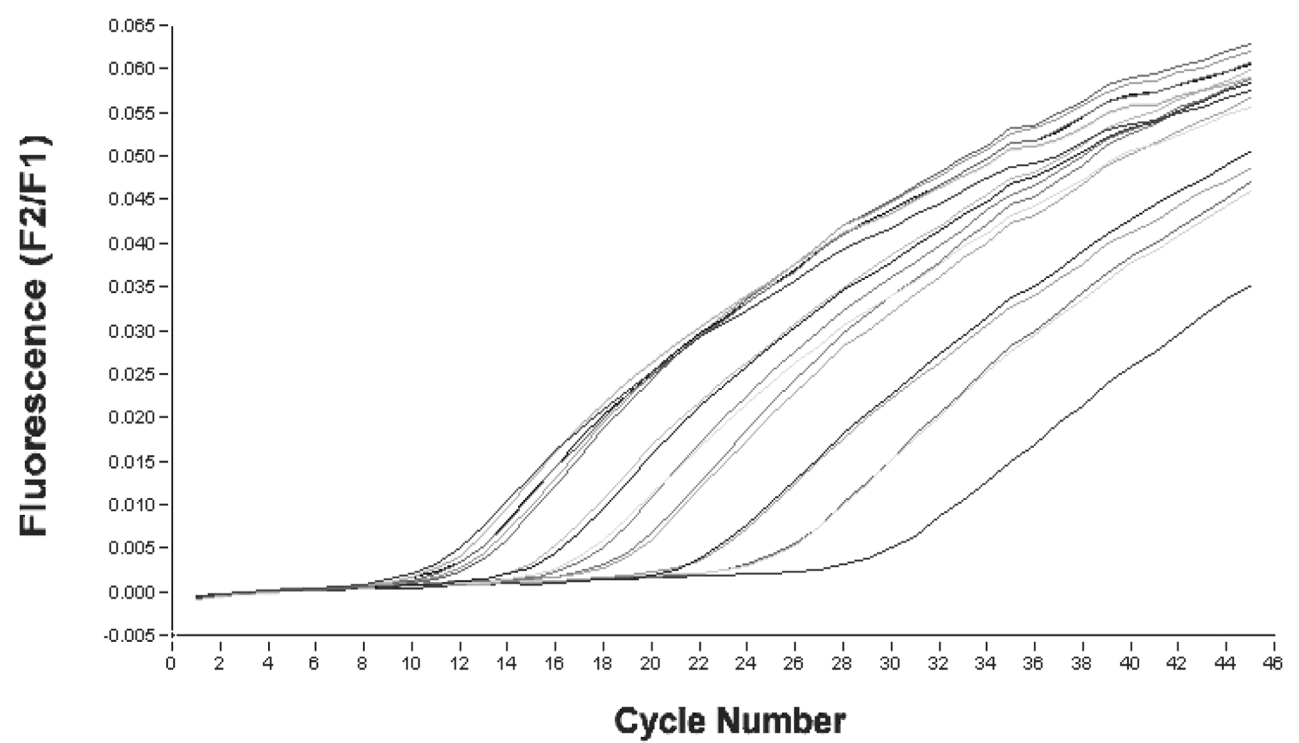

B

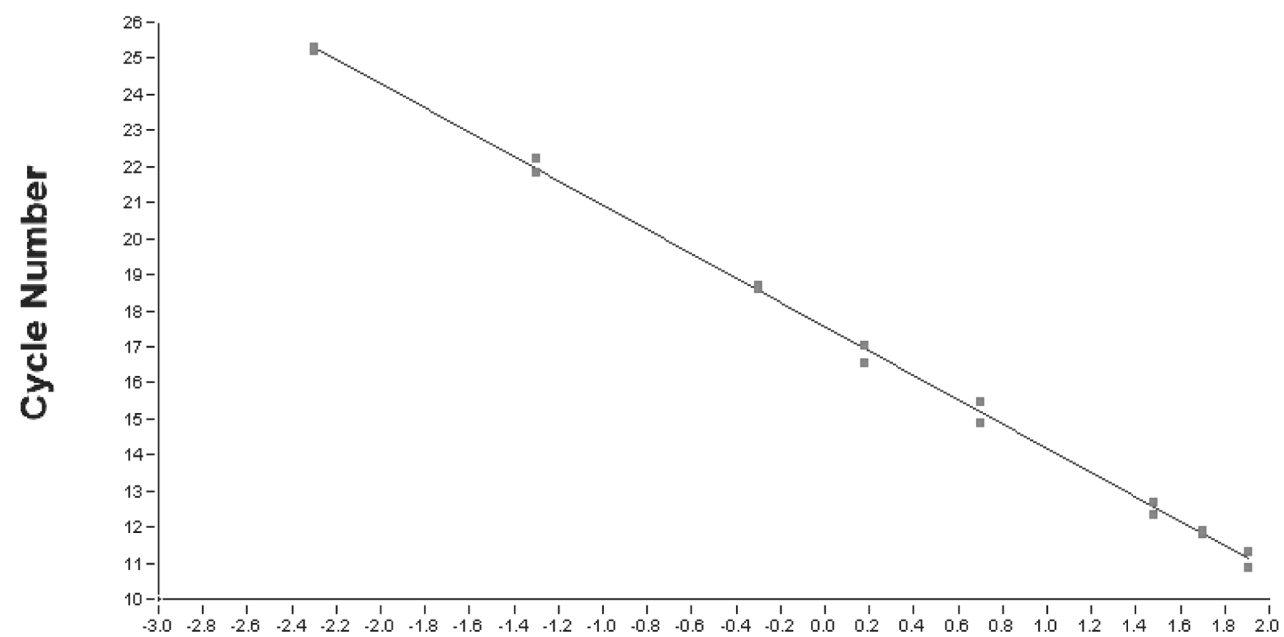

\section{Log Concentration}

C

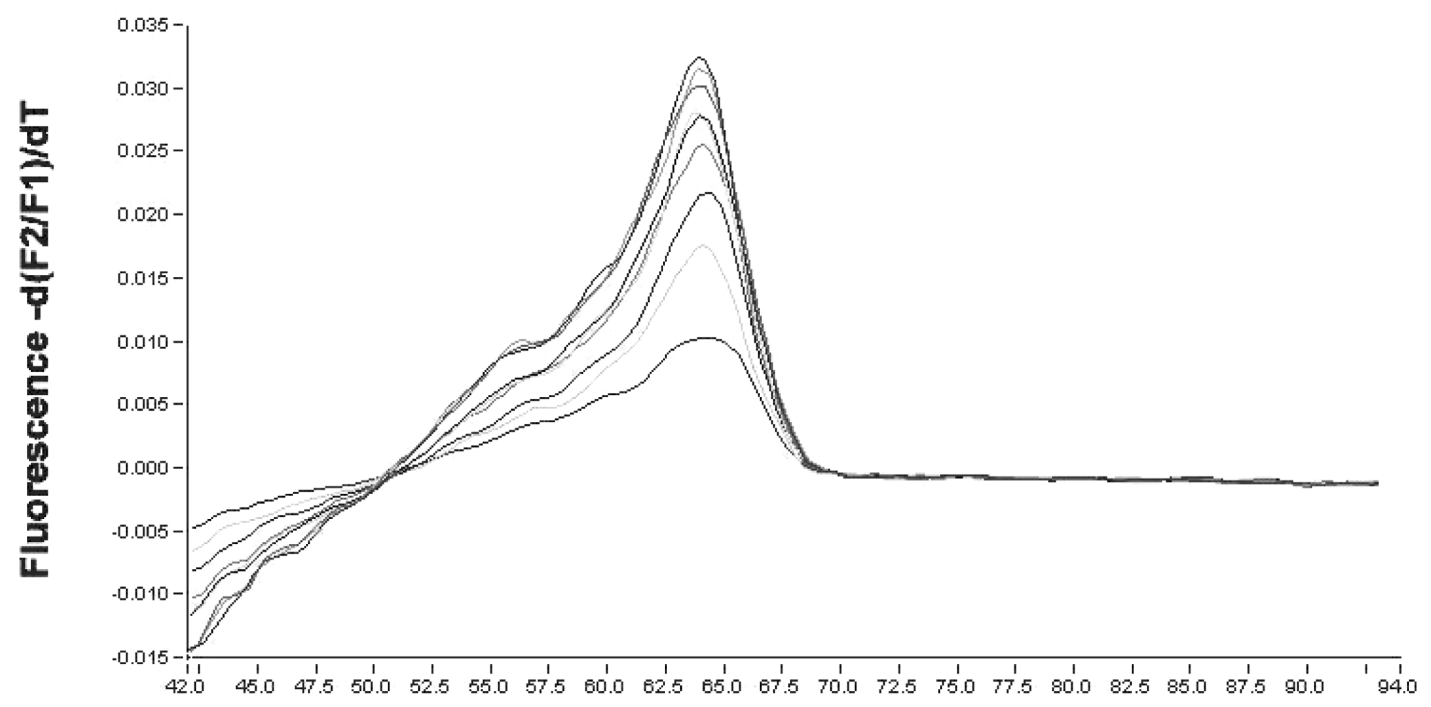


D

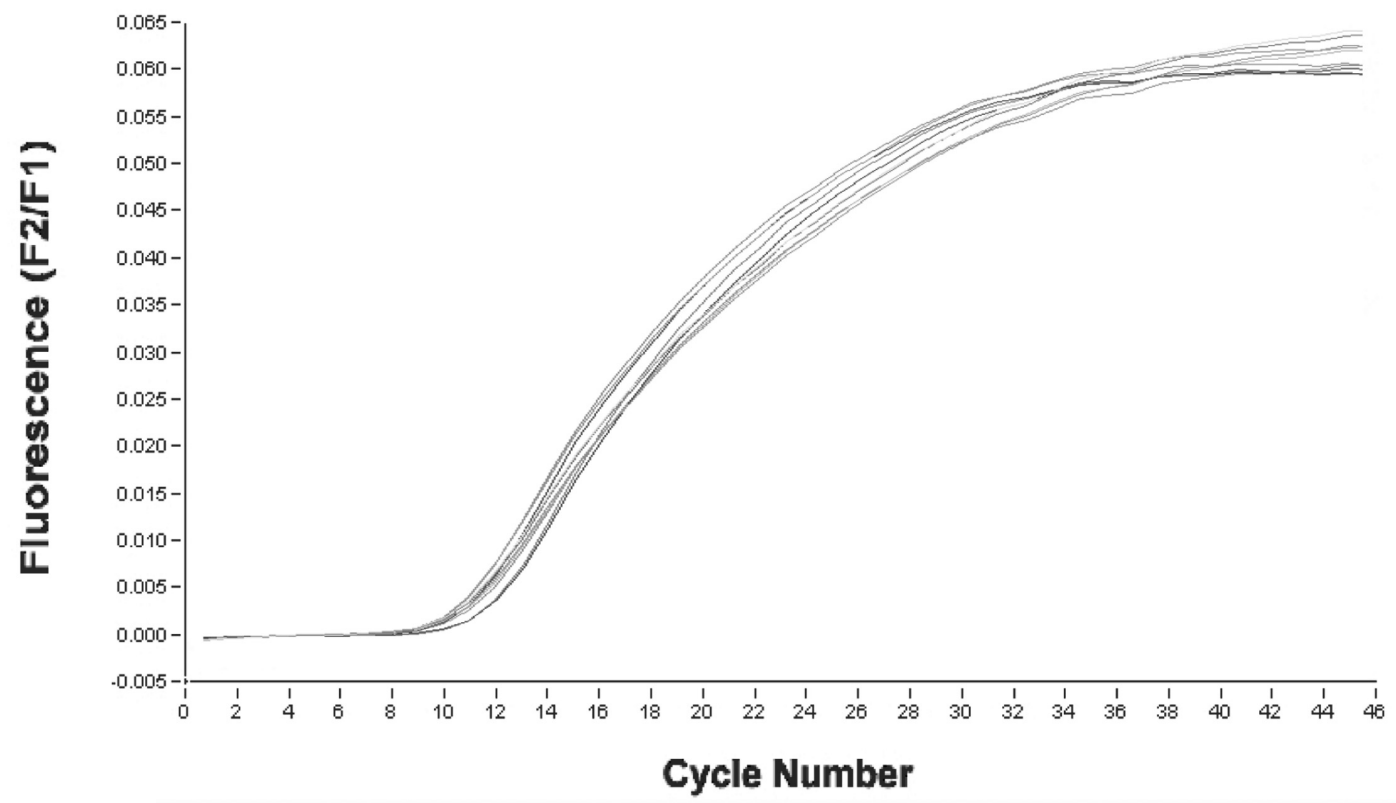

E

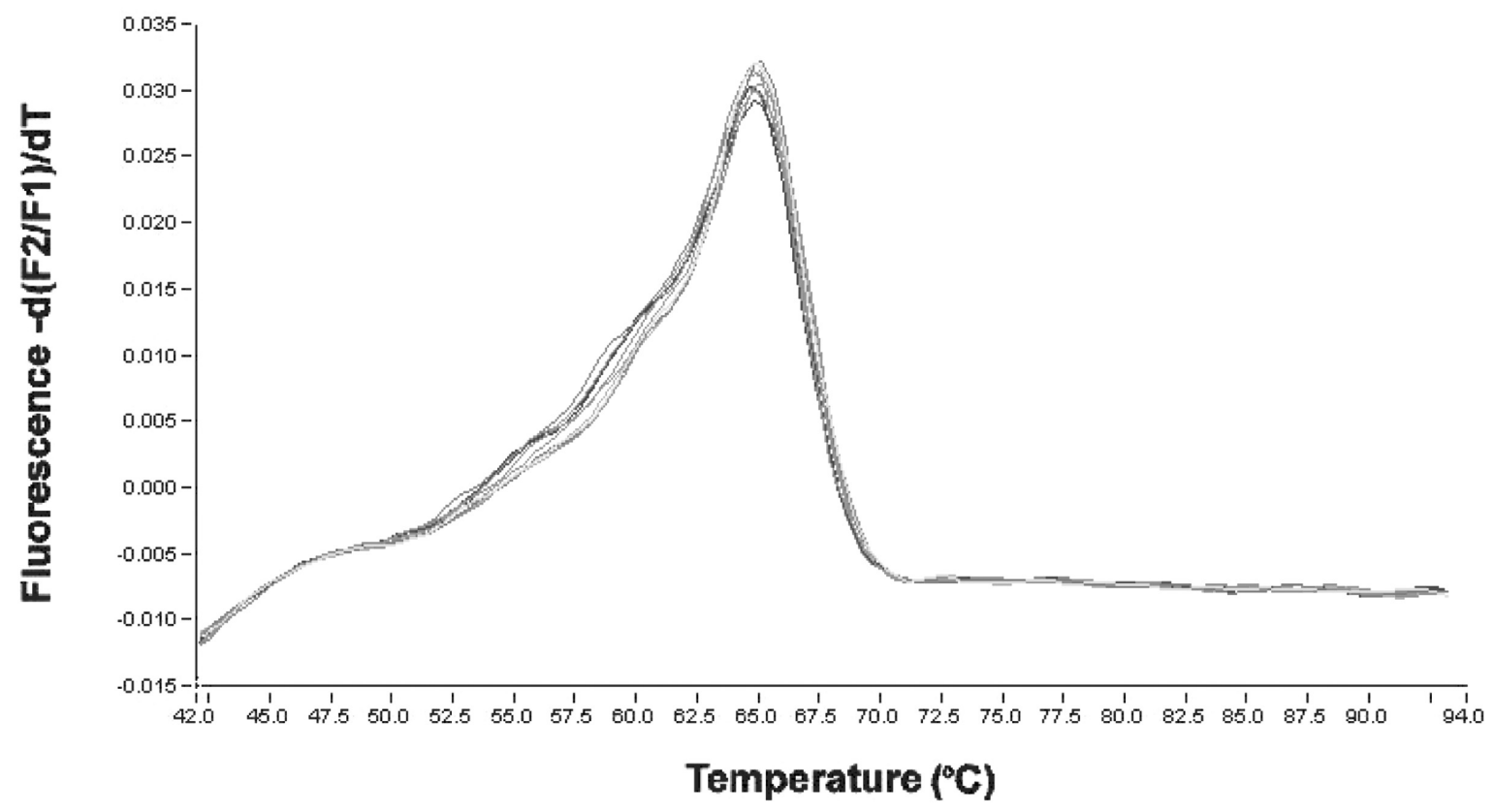

FIG. 2. Representative "spiked" standard curve of $\mathrm{pCMV} \beta$ plasmid for the quantitation of plasmid DNA in tumor tissue and organs. For spiking, pCMV $\beta$ plasmid DNA was serially diluted $(0.005,0.05,0.5,5,10,30,50$, and 80 ng of plasmid DNA) in $250 \mathrm{ng}$ of cellular DNA isolated from the human colon carcinoma cell line SW480. (A) Representative quantitative real-time PCR (LightCycler) of the spiked standard curve, where each plasmid concentration is determined in duplicate. (B) Corresponding linear regression of the standard curve and the intrarun variation $(<6 \%)$. (C) Corresponding melting curves. (D) A representative real-time PCR run and the corresponding melting curves $(\mathbf{E})$ for detection of pCMV $\beta$ plasmid DNA in the tumor of animal 1, 5 min after jet injection, which is also shown in Fig. 4C.

$5 \mathrm{~min}$. The nuclear pellet was washed three times to remove potential cytoplasmic contaminations (see Fig. 6C). To the nuclear pellet (quality of nuclear preparations was evaluated by light microscopy; see Fig. 6C) $1 \mathrm{ml}$ of TRIzol (Invitrogen) was added and the mixture was incubated for $5 \mathrm{~min}$ at room temperature. Thereafter, $0.2 \mathrm{ml}$ of chloroform was added and the mixture was vortexed, incubated for $3 \mathrm{~min}$ at room tempera- ture, and centrifuged at $14,000 \mathrm{rpm}$ at $4^{\circ} \mathrm{C}$. After transfer of the supernatant to another tube, $0.5 \mathrm{ml}$ of isopropanol was added and the mixture was incubated for $10 \mathrm{~min}$ and centrifuged at $14,000 \mathrm{rpm}$ for $10 \mathrm{~min}$ at $4^{\circ} \mathrm{C}$. The DNA pellet was washed with $70 \%$ ethanol and then resuspended in $20 \mu \mathrm{l}$ of TE buffer (pH 7.0). This nuclear DNA was treated with DNase-free RNase and subjected to quantitative real-time PCR analysis for the 
presence of $\mathrm{pCMV} \beta$ in the nuclei. This real-time PCR was performed in duplicate for all reactions.

\section{Confocal laser scanning microscopy}

For confocal laser scanning microscopy, pGeneGRIP jet-injected tumors were removed 5, 30, and 60 min after jet injection, cryosectioned $(13 \mu \mathrm{m})$, and fixed in $3 \%$ formaldehyde for 10 min, dehydrated with acetone, and permeabilized with $0.1 \%$ Triton. After thorough washing in phosphate-buffered saline (PBS), nuclei were stained for 1 min with TO-PRO-3 (Invitrogen Molecular Probes, Eugene, OR), washed with PBS, and dehydrated with $96 \%$ ethanol. The sections were then covered with Faramount (Dako, Carpinteria, CA) and evaluated with an LSM 510 META laser scanning microscope (Carl Zeiss, Jena, Germany) and analyzed with LSM 5 Image Examiner software (Carl Zeiss). Rhodamine was excited with laser light at $488 \mathrm{~nm}$ and TO-PRO3 was excited with laser light at $647 \mathrm{~nm}$. The fluorescence signals were detected with a dichroic beamsplitter UV/488/563/633 and the emission filter BP565-615 (rhodamine) or LP 650 (TOPRO-3). In $z$ stacks the slice thickness was $0.4 \mu \mathrm{m}$ and overlapping slices were used for three-dimensional reconstructions with thresholds according to the labels in the images.

\section{RESULTS}

\section{Intratumoral jet injection and clearance of} plasmid DNA in tumor

To evaluate the biodistribution of jet-injected naked DNA in tumor tissue, animals received a total of $50 \mu \mathrm{g}$ of $\mathrm{pCMV} \beta$ plas- mid DNA by jet injection. We analyzed the DNA load at defined time points after jet injection to evaluate the amount of DNA present within each tumor and to analyze the time course of DNA clearance after jet injection. To accomplish this, we used real-time PCR to quantitate the amount of DNA (see Fig. 2D and E), which was normalized to a standard curve generated by real-time PCR (see Fig. 2A-C) using serial dilutions of spiked $\mathrm{pCMV} \beta$ plasmid DNA as described.

Figure 3 depicts the mean $(n=3)$ total plasmid DNA load in tumors 5, 10, 20, and $40 \mathrm{~min}$ and 3, 6, 24, 48, and $72 \mathrm{hr}$ after jet injection. As shown in Fig. 3, the highest DNA amounts (about $12 \mu \mathrm{g}$ ) were detected 5 min after intratumoral jet injection, representing $24 \%$ of the initial dose of $50 \mu \mathrm{g}$ of jet-injected naked plasmid DNA. In the relatively short period of 10 min after jet injection a rapid drop in DNA load in the tumors was observed. This phase of rapid DNA clearance was followed by a phase of slower elimination rate, which reached a minimum of $0.56-0.04 \mu \mathrm{g}$ of plasmid DNA load 24 to $72 \mathrm{hr}$ after jet injection. This finding is a strong indication that within the first 5 min after jet injection more than $70 \%$ of the initial DNA is cleared from the tumor tissue, which might be attributed to "washout" by the blood flow in the well-vascularized tumors and also by processes of DNA degradation within the tumor.

To obtain more detailed insight concerning the biodistribution of plasmid DNA within tumors, a consecutive series of cryosections covering an entire tumor was analyzed for DNA load at each time point (Fig. 4A). As shown in Fig. 4C and D, in representative tumors from three different animals $5 \mathrm{~min}$ and $24 \mathrm{hr}$ after jet injection, a heterogeneous distribution of plasmid DNA was determined. This is reflected by the variations seen in DNA concentration in the various tumor fractions; this

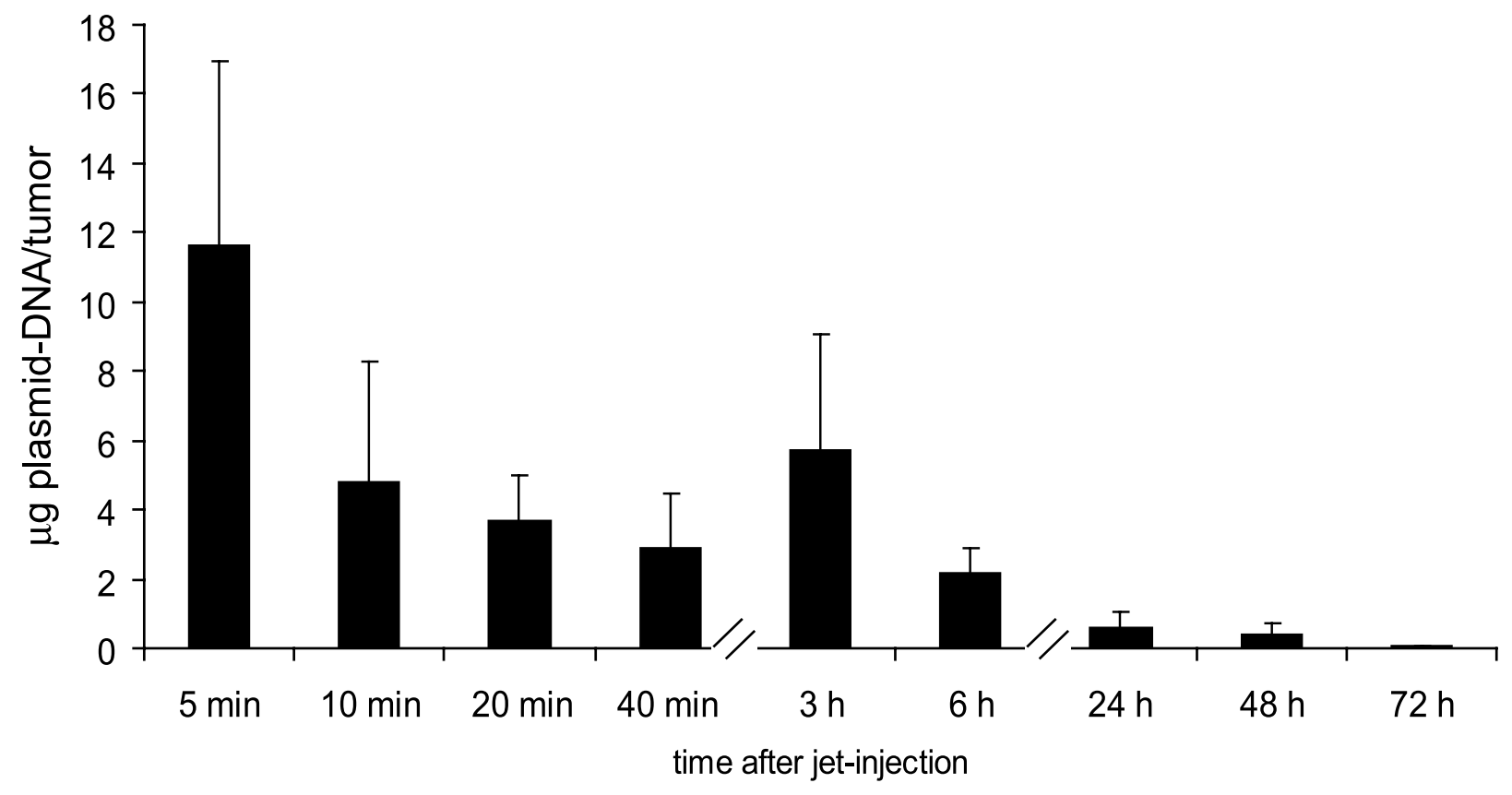

FIG. 3. Analysis of time-dependent intratumoral DNA load, that is, jet-injected pCMV $\beta$ plasmid. Columns represent mean total plasmid load in three different animals for each time point after jet injection of the initial dose of $50 \mu \mathrm{g}$ of DNA per tumor. Quantification of plasmid DNA was performed in duplicate by real-time PCR (LightCycler), using a spiked plasmid DNA standard curve for each quantification analysis. (Error bars represent the SD.) 


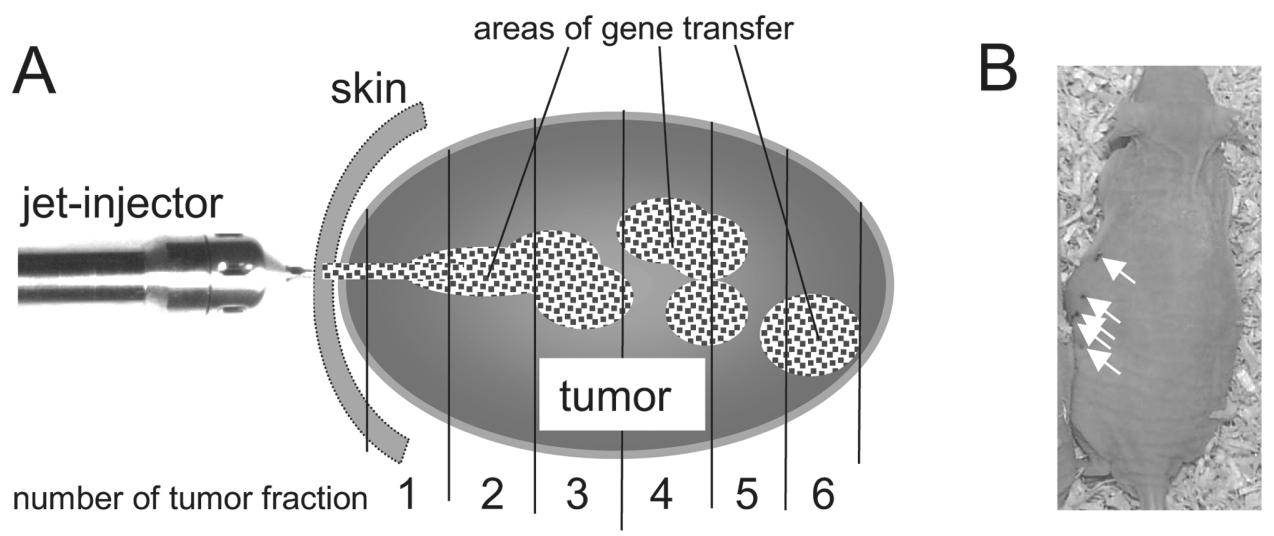

C
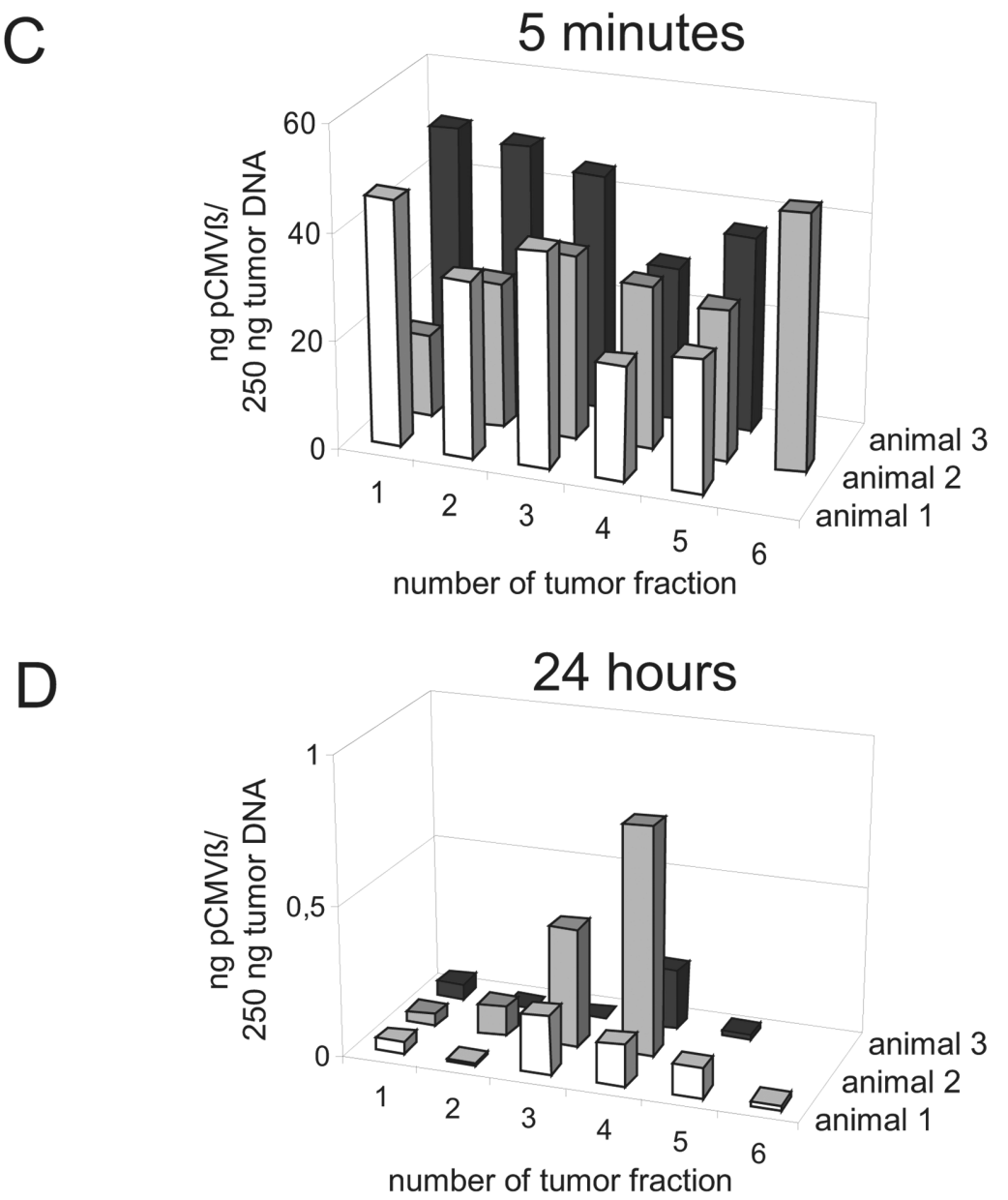

FIG. 4. Detailed real-time PCR analysis of intratumoral biodistribution of pCMV $\beta$ plasmid DNA 5 min and 24 hr after jet injection. (A) Schematic representation of tumor fractionation for real-time PCR analysis after jet injection: fractions 1 to 6 were generated by cryosectioning of each tumor, in order to represent the entire tumor. (B) The five sites of jet injections (indicated by arrows) of a tumor-bearing animal. (C) Intratumoral plasmid distribution in three different animals 5 min after jet injection. (D) Intratumoral plasmid distribution in three different animals $24 \mathrm{hr}$ after jet injection. The amounts of plasmid DNA shown were detected in $250 \mathrm{ng}$ of tumor DNA and were determined in duplicate for each time point.

might be due to the physical characteristics of the tissue-penetrating jet (Fig. 4A). However, for both representative time points, plasmid DNA was detected throughout the entire tumor tissue (represented by the six cryosection fractions), although at different concentration levels (Fig. 4C and D). In fact, similar patterns of plasmid distribution were also shown for all other time points, including 48 and $72 \mathrm{hr}$ after jet injection (data not shown). 

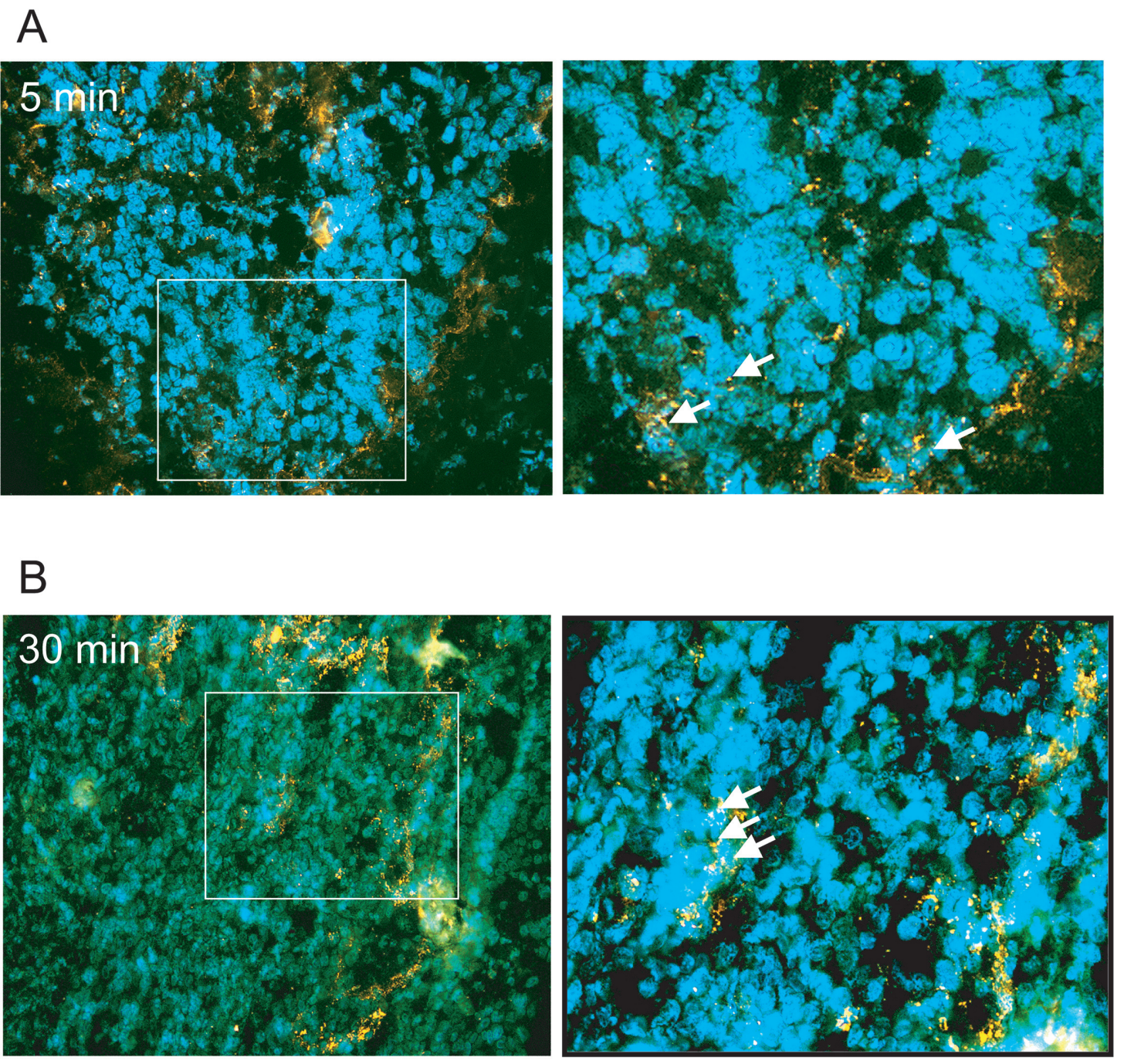

\section{C}
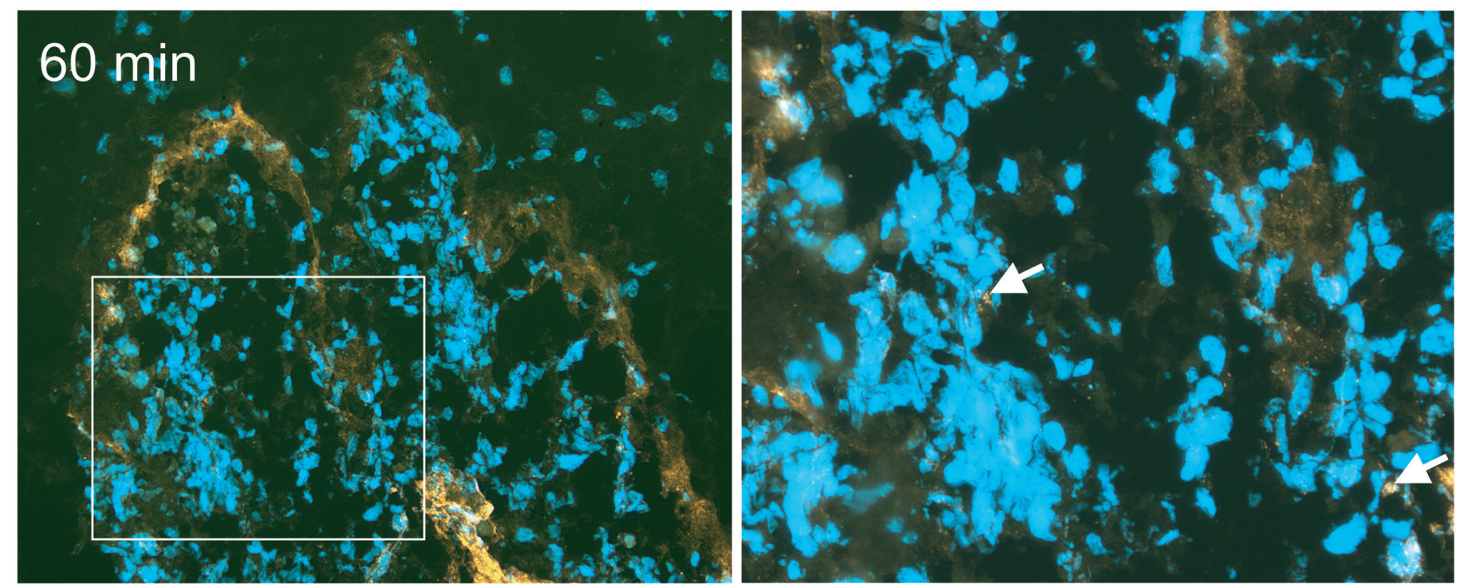

FIG. 5. Distribution of rhodamine-labeled pGeneGRIP plasmid DNA in tumor tissue after intratumoral jet injection, as analyzed by fluorescence microscopy. (A-C) Tissue distribution of rhodamine-labeled DNA (orange/red) 5, 30, and 60 min, respectively, after jet injection. Plasmid DNA is localized within the intercellular space and within the tumor cells (indicated by arrows). Cell nuclei are stained blue. Microphotographs on the left are taken at an original magnification of $\times 60$, those on the right at an original magnification of $\times 100$. 


\section{Cellular localization of rhodamine-labeled plasmid DNA after intratumoral jet injection}

To analyze at the tissue and cellular levels the fate of naked DNA jet-injected into tumor, we used rhodamine-labeled pGeneGRIP plasmid DNA for in vivo jet injection. Five, 30, and 60 min after jet injection tumors were analyzed for localization of the labeled DNA, using fluorescence microscopy and confocal laser scanning microscopy.

Figure 5 depicts the pattern of plasmid distribution in jet-injected tumors. Plasmid DNA is localized mainly in the intercellular space; some can also be found within the tumor cells. The microphotographs in Fig. 5 demonstrate the inhomogeneous spread pattern of plasmid DNA, which was generated by the jet force in the tissue and that is in agreement with data obtained by real-time PCR analysis (see Fig. 4).

To obtain a more detailed picture of plasmid DNA localization at the cellular level, tumors were analyzed by confocal scanning laser microscopy. The microphotographs in Fig. 6A show that as soon as 5 min after jet injection plasmid DNA was detected within tumor cells. Thirty to 60 min after jet injection a further increase in intracellular and perinuclear accumulation of labeled DNA was seen. More interestingly, clear nuclear penetration of labeled plasmid DNA was detectable 30 and $60 \mathrm{~min}$ after jet injection (Fig. 6A). To evaluate whether such nuclear localization had already initiated as early as $5 \mathrm{~min}$ after jet injection, three-dimensional ( $z$ stack) analysis of the confocal laser scanning images was performed. As shown in Fig. 6B, small proportions of rhodamine-labeled plasmid DNA were localized in the cell nuclei of tumor tissue 5 min after jet injection.

To quantitatively complement these findings by confocal laser scanning microscopy, DNA from cell nuclei was isolated from the same tumor tissues shown in Fig. 6A and quantitative real-time PCR was performed to detect plasmid DNA. The purity of nuclear preparations was evaluated by light microscopy and by control of the washing buffer of the nuclear pellet for the presence of plasmid contamination (Fig. 6C). The results depicted in Fig. 6D support our previous observation that, indeed, 5 min after jet injection small amounts of plasmid DNA (0.06 pg of plasmid DNA per $250 \mathrm{ng}$ of nuclear DNA) were detectable in the cell nuclei. Over time a rapid nuclear plasmid accumulation was observed, reflected by an 13 -fold increase in DNA load from $0.21 \mathrm{pg}$ of plasmid DNA per $250 \mathrm{ng}$ of nuclear DNA 30 min after jet injection to $2.8 \mathrm{pg}$ of plasmid DNA per $250 \mathrm{ng}$ of nuclear DNA $60 \mathrm{~min}$ after jet injection. These data provide evidence that jet injection permits rapid intratumoral and, more importantly, intracellular penetration of naked plasmid DNA associated with almost simultaneous nuclear localization of small proportions of jet-injected DNA.

\section{Systemic biodistribution of plasmid DNA after intratumoral jet injection}

Besides the analysis of the distribution of plasmid DNA within tumors, it is of crucial importance to monitor the systemic biodistribution of applied naked DNA. To accomplish this, we analyzed by real-time PCR samples of blood, liver, lung, kidney, spleen, ovary, heart, brain, and bone marrow from all treated animals at all time points after jet injection. This quantitative analysis was performed to provide information about the time-dependent biodistribution in these particular or- gans and the clearance of the DNA. Figure 7 shows the results for systemic plasmid biodistribution after intratumoral jet injection. Although at much lower plasmid DNA concentrations in the various organs ( $>240$-fold lower compared with tumors), systemic leakage of the intratumorally jet-injected DNA was seen. Five minutes after intratumoral jet injection the highest level of plasmid DNA was observed in the blood of the animals (Fig. 7A). However, the plasmid concentration rapidly dropped from about 48 to less than 5 pg of plasmid DNA per $250 \mathrm{ng}$ of blood DNA within 20 min of jet injection. This decline in plasmid DNA in the blood of the animals was paralleled by the increase in plasmid DNA in the various organs, particularly in liver, lung, and kidney and at a much lower level in ovaries, spleen, brain, bone marrow, and heart (Fig. 7B and Table 1). On comparing the DNA load in the various organs, the highest plasmid DNA concentrations were found in liver (37 pg of plasmid DNA per $250 \mathrm{ng}$ of liver DNA) and lung (31 pg of plasmid DNA per $250 \mathrm{ng}$ of lung DNA) 20 min after jet injection; these concentrations rapidly dropped within $40 \mathrm{~min}$ of jet injection and were almost completely cleared after $6 \mathrm{hr}$ (Fig. 7A and Table 1). An almost similar DNA clearance was observed in the kidneys. Only in one of three animals was a delayed clearance observed $3 \mathrm{hr}$ after jet injection (Fig. 7A and Table 1), whereas at this time point in the kidneys of the other animals only low amounts of plasmid DNA $(<0.3 \mathrm{pg}$ of plasmid DNA per 250 ng of kidney DNA) were detectable. The lowest plasmid DNA concentrations were determined in the brain and heart of the animals (Fig. 7B). Taken together, in all organs (except blood) the highest plasmid DNA concentrations were most frequently measured within 40 min of jet injection, whereas clearance of this DNA was completed as soon as 3 to $6 \mathrm{hr}$ after intratumoral jet injection. This is supported by the summarized data in Table 1, showing that $6 \mathrm{hr}$ after intratumoral jet injection none of the animals tested positively for pCMV $\beta$ DNA in the organs (except blood).

\section{Analysis of intratumoral and systemic LacZ expression after jet injection of $p C M V \beta$ plasmid DNA}

To determine to what extent jet-injected $\mathrm{pCMV} \beta$ plasmid DNA is transcriptionally active in jet-injected tumors and might also exert LacZ expression in other sites via systemic distribution, we tested LacZ mRNA expression in tumors and in organs (blood, liver, lung, kidney, ovary, spleen, brain, bone marrow, and heart), using real-time RT-PCR. Table 2 shows that in jet-injected tumors LacZ mRNA expression is detectable 24 $\mathrm{hr}$ after jet injection, reflected by a 322-fold relative expression level compared with stably LacZ-expressing SW480 calibrator cells. This mRNA expression remains at a high level $48 \mathrm{hr}$ after jet injection, followed by a decline in expression level after $72 \mathrm{hr}$. In addition, the other organs and blood were tested for LacZ expression at all time points $(5,10,20$, and $40 \mathrm{~min}$ and $3,6,24,48$, and $72 \mathrm{hr}$ ) after jet injection; however, we could not detect LacZ mRNA at these sites, although the real-time PCR detected plasmid DNA in all these tissues. Even those organs with the highest $\mathrm{pCMV} \beta$ concentrations, such as liver, lung, and kidney, did not express LacZ-specific mRNA. In fact, this is a strong indication that systemic biodistribution of intratumorally jet-injected DNA is not associated with transcriptional activity in other sites than the targeted tumor. 
A
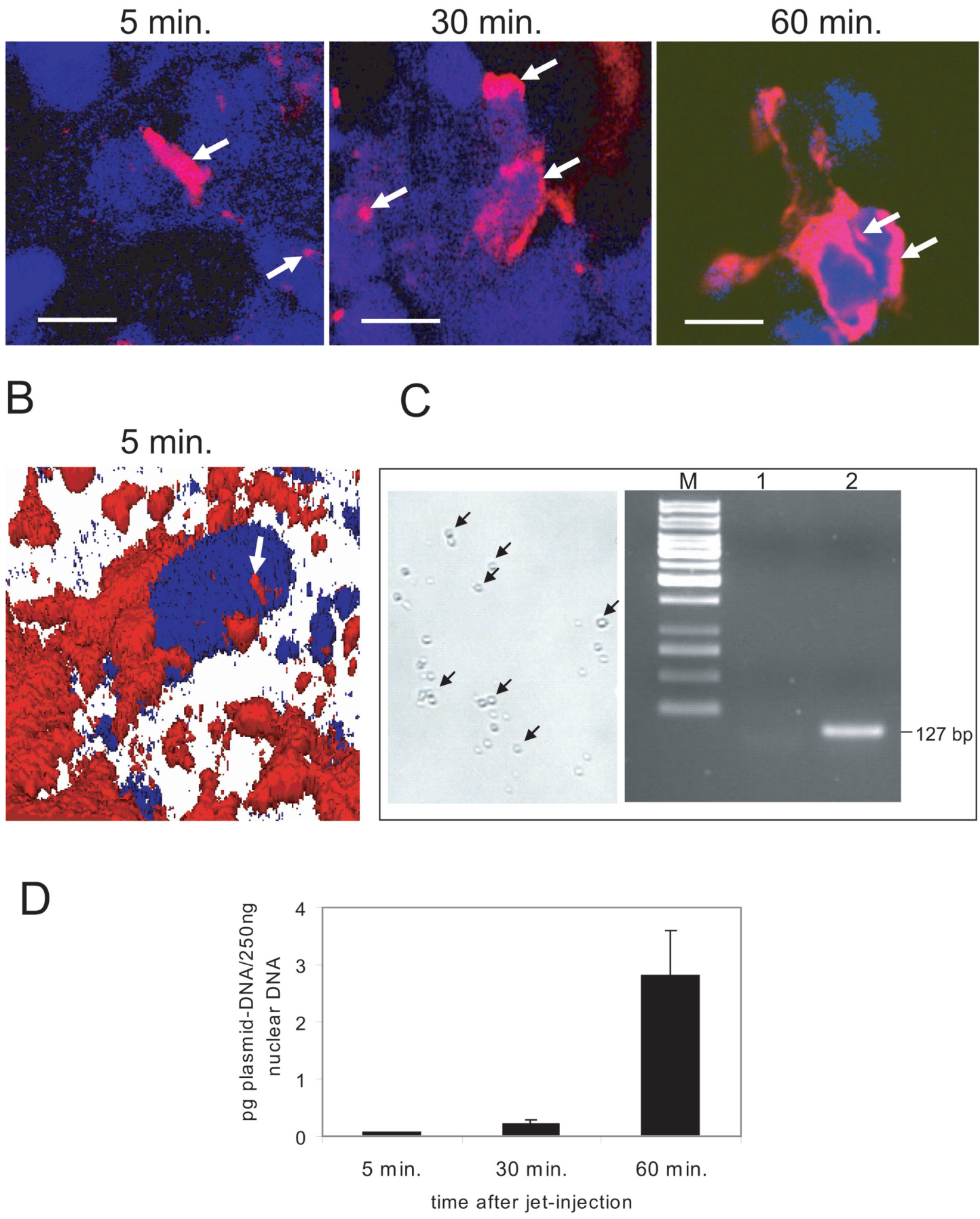

FIG. 6. Intracellular distribution of rhodamine-labeled pGeneGRIP plasmid DNA 5, 30, and 60 min after intratumoral jet injection, as analyzed by confocal laser scanning microscopy. (A) Time-dependent distribution of plasmid DNA (red) in the perinuclear space and within the cell nuclei (blue) in jet-injected tissues (indicated by arrows). Scale bars: $5 \mu \mathrm{m}$. (B) A more detailed three-dimensional reconstitution of a $z$ stack acquired by confocal laser microscopy, displaying a tumor cell 5 min after jet injection with perinuclear and intranuclear localization (arrow) of labeled plasmid DNA (red); nucleus (blue). (C) Quality control of the nuclear preparation from tumor tissue $60 \mathrm{~min}$ after jet injection. Left: Control of nuclear preparation by light microscopy (nuclei are indicated by arrows). Right: Agarose gel electrophoresis of the pCMV $\beta$-specific PCR of the washing buffer of the nuclear pellet (lane 1; lane M, 1-kb DNA ladder) and of the DNA preparation from the nuclei (lane 2). The plasmid-specific amplicon (127 bp) is indicated. (D) Quantitative real-time PCR analysis of plasmid DNA presence in the nuclei of tumors 5,30 , and 60 min after jet injection, using $250 \mathrm{ng}$ of nuclear DNA. 

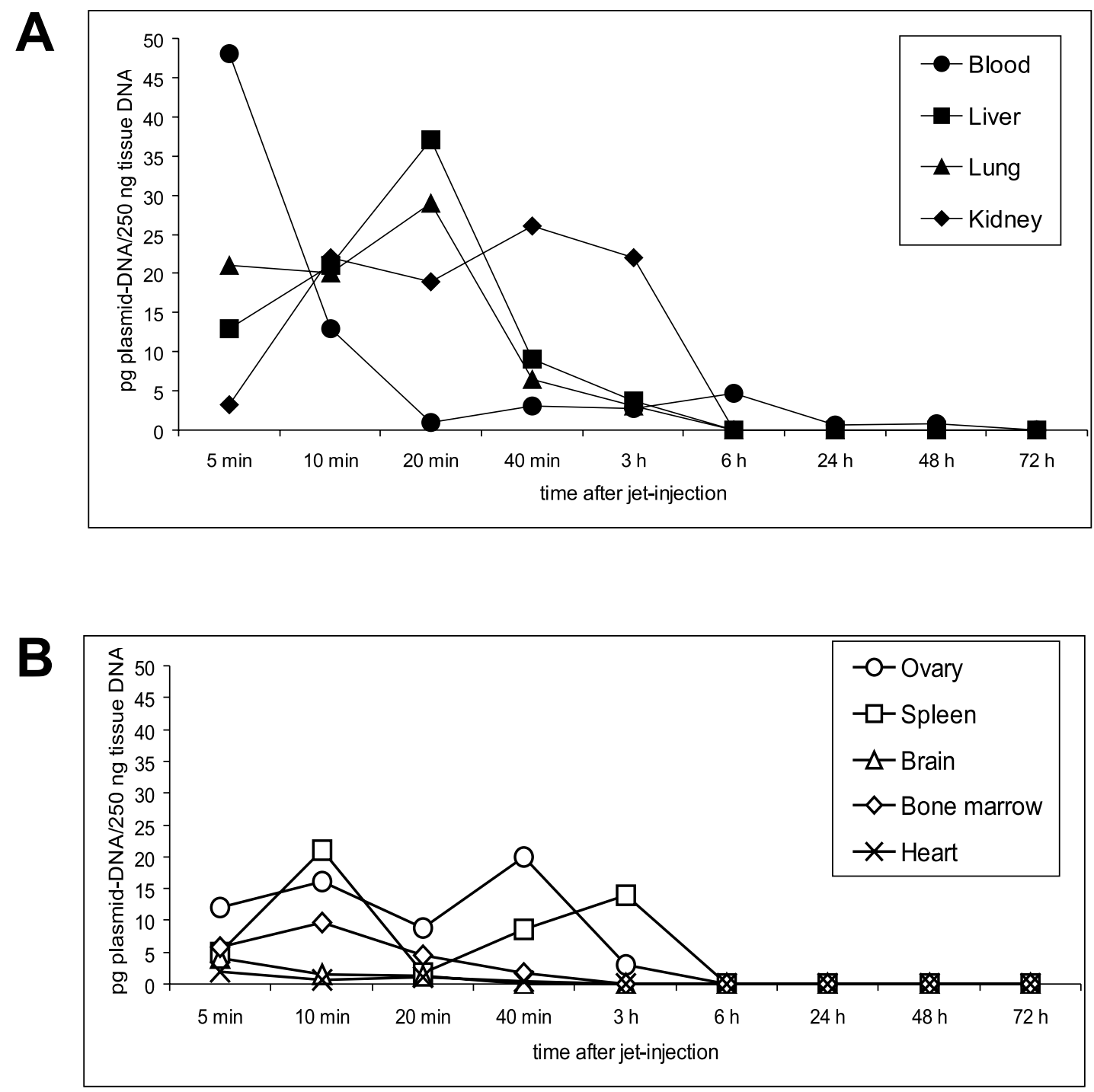

FIG. 7. Time-dependent biodistribution of $\mathrm{pCMV} \beta$ plasmid DNA in the blood and various organs of animals after intratumoral jet injection, represented by the highest value of DNA load in the respective organs for each animal group. The plasmid DNA was quantified by real-time PCR (LightCycler) in each organ, using a spiked plasmid DNA standard curve for each quantification analysis. Each time point is represented by the mean value obtained in duplicate in the respective samples. The amounts of plasmid DNA shown were determined in $250 \mathrm{ng}$ of blood DNA (whole blood) or in the respective organ tissue DNA. (A) Biodistribution in blood, liver, lung, and kidney; (B) biodistribution in ovary, spleen, brain, bone marrow, and heart. The SD was much less than $10 \%$ for all values determined.

\section{DISCUSSION}

In this in vivo study we investigated the time course of clearance and biodistribution of naked plasmid DNA applied intratumorally by jet injection. Previous in vivo studies have demonstrated that this nonviral gene transfer technology is efficient for transfer of various vector constructs in different tissue types, leading to effective expression of the respective transgenes (Ren et al., 2002; Walther et al., 2004). Because nothing is known about the in vivo fate of focally jet-injected naked DNA in tumors or about its systemic biodistribution and clearance, our study has focused on this issue, using quantitative real-time PCR. For this we applied $50 \mu \mathrm{g}$ of $\mathrm{pCMV} \beta$ DNA by jet injec- tion, knowing that such dosing had been shown to be effective for transgene expression in tumor tissue in vivo (Walther et al., 2001, 2002).

In this study we have shown that shortly after jet injection a high proportion (more than 70\%) of naked DNA is lost in the tumors. The effect of such rapid losses in DNA has also been reported in other studies, where naked DNA was applied by needle injection into muscle, liver, or tumors (Parker et al., 1999; Dupuis et al., 2000; Herweijer et al., 2001; Cappelletti et al., 2003; Kawase et al., 2003). Because jet injection applies only small volumes at high pressure, the potential effect of seepage of the jet-injected volume is negligible and does not contribute to quantitative losses of DNA. When correlating this ob- 
Table 1. Maximum Plasmid DNA Load at the Indicated Time Points in Various Tissues of Animals and Number of Tissues Positively Tested for Plasmid DNA for Each Time Point AFter InTRATUMORAL Jet INJECTION ${ }^{\mathrm{a}}$

\begin{tabular}{|c|c|c|c|c|c|c|c|c|c|c|}
\hline \multirow[b]{2}{*}{ Organ } & \multirow{2}{*}{$\begin{array}{c}\text { Maximum plasmid } \\
\text { concentration } \\
\text { (pg plasmid DNA/ } \\
250 \text { ng tissue DNA) at } \\
\text { indicated time (min) }\end{array}$} & \multicolumn{9}{|c|}{ Number of tissues positive for plasmid DNA for each animal group $(n=3)$} \\
\hline & & $5 \min ^{\mathrm{b}}$ & $10 \min ^{\mathrm{b}}$ & $20 \min ^{\mathrm{b}}$ & $40 \min ^{\mathrm{b}}$ & $3 h r^{b}$ & $6 h r^{\mathrm{b}}$ & $24 h r^{\mathrm{b}}$ & $48 h r^{\mathrm{b}}$ & $72 h r^{\mathrm{b}}$ \\
\hline Blood & $48(5)$ & $2 / 3$ & $3 / 3$ & $3 / 3$ & $3 / 3$ & $3 / 3$ & $3 / 3$ & $0 / 3$ & $0 / 3$ & $0 / 3$ \\
\hline Liver & $37(20)$ & $3 / 3$ & $3 / 3$ & $2 / 3$ & $1 / 3$ & $3 / 3$ & $0 / 3$ & $0 / 3$ & $0 / 3$ & $0 / 3$ \\
\hline Lung & $31(20)$ & $3 / 3$ & $3 / 3$ & $2 / 3$ & $2 / 3$ & $3 / 3$ & $0 / 3$ & $0 / 3$ & $0 / 3$ & $0 / 3$ \\
\hline Kidney & $26(40)$ & $3 / 3$ & $2 / 3$ & $2 / 3$ & $2 / 3$ & $1 / 3$ & $0 / 3$ & $0 / 3$ & $0 / 3$ & $0 / 3$ \\
\hline Ovary & $25(40)$ & $3 / 3$ & $3 / 3$ & $2 / 3$ & $2 / 3$ & $3 / 3$ & $0 / 3$ & $0 / 3$ & $0 / 3$ & $0 / 3$ \\
\hline Spleen & $20(10)$ & $0 / 3$ & $3 / 3$ & $3 / 3$ & $2 / 3$ & $2 / 3$ & $0 / 3$ & $0 / 3$ & $0 / 3$ & $0 / 3$ \\
\hline Brain & $4(5)$ & $2 / 3$ & $2 / 3$ & $3 / 3$ & $0 / 3$ & $3 / 3$ & $0 / 3$ & $0 / 3$ & $0 / 3$ & $0 / 3$ \\
\hline Heart & $3(40)$ & $3 / 3$ & $3 / 3$ & $2 / 3$ & $2 / 3$ & $0 / 3$ & $0 / 3$ & $0 / 3$ & $0 / 3$ & $0 / 3$ \\
\hline Bone marrow & $2(4)$ & $3 / 3$ & $3 / 3$ & $2 / 3$ & $1 / 3$ & $0 / 3$ & $0 / 3$ & $0 / 3$ & $0 / 3$ & $0 / 3$ \\
\hline
\end{tabular}

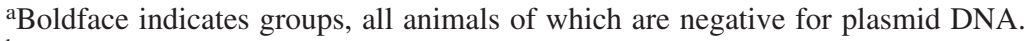

${ }^{\mathrm{b}}$ Time after jet injection.

servation of rapid decrease in DNA concentration in tumors with our finding of a significant increase in plasmid DNA in the blood within 5 min of jet injection, we conclude, that a proportion of jet-injected DNA is dispersed by the blood flow, contributing to the observed intratumoral losses. Such blood-mediated dispersion shortly after DNA application has also been observed by others after intramuscular or intratumoral administration of plasmid DNA (Parker et al., 1999; Kawase et al., 2003). Although solid tumors often possess elevated hydrostatic pressure that hinders DNA dispersion, high tumor vascularization with regions of hyperpermeable endothelium might augment dispersion of jet-injected DNA from the injection site to the intracellular space (Baban and Seymour, 1998; Pouton and Seymour, 2001). In addition, degradative processes, such as nuclease activities in the target tissue, will contribute to the quantitative loss of intact plasmid DNA (Cappelletti et al., 2003; Walther et al., 2005). We have shown, in a previous study, that particularly in tumor tissues high nucleolytic activities can be detected, causing more than $70 \%$ DNA degradation within 5 to 10 min of jet injection (Walther et al., 2005). Despite the observed tremendous loss of jet-injected DNA within tumors, previous studies and this study have demonstrated that the remaining small proportions of plasmid DNA $(<0.07 \%, 72 \mathrm{hr}$ after jet injection) lead to transgene expression. In addition, our detailed analysis of plasmid distribution within tumor tissues clearly showed that jet injection permits inhomogeneous plas- mid distribution and does affect the entire tissue (Fig. 4C and D, and Fig. 5). This represents an important prerequisite for effective transgene expression within tumors.

To gain more detailed insight into the in vivo path of jet-injected plasmid DNA, particularly shortly after application, we performed confocal scanning microscopy analysis with rhodamine-labeled DNA. As we have observed in these analyses, the majority of labeled DNA was typically localized within the intercellular space shortly after jet injection, which is in agreement with observations made in another, similar study of naked DNA gene transfer (Dupuis et al., 2000). More interestingly, we have seen the rapid entry of labeled DNA into the cytoplasm and to a lesser extent into cell nuclei as early as $5 \mathrm{~min}$ after in vivo jet injection, followed by a significant increase in nuclear accumulation within 30 to $60 \mathrm{~min}$. Regarding this issue, different kinetics of cellular DNA uptake were determined by other investigators, varying from cytoplasmic uptake in only a few minutes after application of naked DNA to several hours (24 hr) in injected muscle or in hepatic tissue after tail vein injection (Budker et al., 2000; Dupuis et al., 2000). Our observation of plasmid DNA localization in the cytoplasm and cell nuclei shortly after jet injection might be the result of the high energy by which jet injection forces DNA into tumor tissue. Such a mode of application could have similar effects as shown, for example, in the hydrodynamic procedure leading to transient close DNA:cell contact as a pressure-dependent effect,

Table 2. Maximum Relative LacZ mRNA Expression Level in Jet-Injected Tumors Compared with LacZ Expression in Stably pCMV $\beta$-Transduced SW480 Human Colon Carcinoma Cell Line ${ }^{a}$

\begin{tabular}{cc}
\hline Time after jet injection $(\mathrm{hr})$ & Fold LacZ expression relative to calibrator cell line (SW480) \\
\hline 24 & 322 \\
48 & 111 \\
72 & 6.6 \\
\hline
\end{tabular}

Calibrator; data determined by real-time RT-PCR (LightCycler) in duplicate. 
which in turn augments cellular DNA uptake (Zhang et al., 1997). Summarizing these findings, jet injection seems to positively influence the process of partitioning of plasmid DNA between the intracellular and intercellular space associated with any nonviral application of DNA by promoting rapid cellular uptake and nuclear translocation (Bureau et al., 2004).

Regarding the systemic biodistribution of plasmid DNA, we detected $\mathrm{pCMV} \beta$ DNA in the blood shortly after intratumoral jet injection; clearance occurred rapidly. Interestingly, this clearance of DNA from the blood correlated with the increase in plasmid DNA concentration in those organs particularly known to be well-vascularized tissues (e.g., liver, lung, and spleen). Therefore, dispersion of plasmid DNA from the circulation might lead to the observed short and time-restricted appearance of plasmid DNA in the other organs, which is then rapidly cleared within $6 \mathrm{hr}$ of jet injection. Interestingly, similar kinetics of biodistribution for nonvirally applied DNA have been described by several authors in various in vivo models (Parker et al., 1999; Kawase et al., 2003; Bureau et al., 2004). Our observation of complete clearance from all organs within $6 \mathrm{hr}$ of jet injection is important regarding the safety of this technology. We needed to analyze whether such dispersion of plasmid DNA might lead to unwanted expression of the transgene. As shown by real-time RT-PCR analysis in all organs, no such expression was determined at any time. These results give strong evidence that systemic distribution of plasmid DNA after intratumoral jet injection is not sufficient to generate gene transfer and transgene expression outside the actual jet-injected tumor tissue. One major explanation for this could be that the major compartment for the biodistribution of plasmid DNA is the rapidly circulating blood, by which DNA travels from the tumor to the various organs. It has been suggested, however, that such systemic DNA distribution occurs with insufficient time and proximity to the hypothesized DNA receptors on cells of these organs to permit endocytosis for efficient gene transfer (Liu and Huang, 2002). This is supported by the finding that occlusion of the blood stream significantly improves gene transfer of naked DNA by increasing the retention time for the DNA applied (Liu and Huang, 2002). Another explanation for the absence of gene expression in the various organs is that no physical energy forces the uptake of naked DNA into the cells of these organs.

In conclusion, our quantitative and qualitative analysis revealed that the topical application of naked plasmid DNA to tumors leads to efficient gene transfer and transgene expression. This expression was limited to the primary injection site, despite the fact that leakage of jet-injected DNA into other organs has been shown after intratumoral jet injection. In these organs, in particular, the rapid systemic clearance of plasmid DNA has been observed. These results support the notion that in vivo jet injection is a safe nonviral technology for gene therapy approaches.

\section{ACKNOWLEDGMENTS}

The authors thank M. Lemm for excellent technical assistance, and W. Haensch for histopathological evaluation of tumor samples. This work was kindly supported by Electro Medical Systems (Nyon, Switzerland) and the Deutsche Forschungsgemeinschaft (DFG).

\section{REFERENCES}

BABAN, D.F., and SEYMOUR, L.W. (1998). Control of tumour vascular permeability. Drug Deliv. Rev. 3, 109-119.

BUDKER V, BUDKER, T., ZHANG, G., SUBBOTIN, V., LOOMIS, A., and WOLFF, J.A. (2000). Hypothesis: Naked plasmid DNA is taken up by cells in vivo by a receptor-mediated process. J. Gene Med. 2, 76-88.

BUREAU, M.F. , NAIMI, S. , IBAD, R.T. , SEGUIN, J. , GEORGER, C., ARNOULD, E., MATON, L., BLANCHE, F., DELAERE, P., and SCHERMAN, D. (2004). Intramuscular plasmid DNA electrotransfer biodistribution and degradation. Biochim. Biophys. Acta 1676, 138-148.

CAPPELlETTI, M., ZAMPAGLIONE, I., RIZZUTO, G., CILIBERTO, G., LA MONICA, N., and FATTORI, E. (2003). Gene electro-transfer improves transduction by modifying the fate of intramuscular DNA. J. Gene Med. 5, 324-332.

CARTIER, R., REN, S.V., WALTHER, W., STEIN, U., LEWIS, A., SCHLAG, P.M., LI, M., and FURTH, P.A. (2000). In vivo gene transfer by low-volume jet injection. Anal. Biochem. 282, 262-265.

DUPUIS, M., DENIS-MIZE, K. , WOO, C., GOLDBECK, C., SELBY, M.J., CHEN, M., OTTEN, G.R., ULMER, J.B., DONNELLY, J.J., OTT, G., and McDONALD, D.M. (2000). Distribution of DNA vaccines determines their immunogenicity after intramuscular injection in mice. J. Immunol. 165, 2850-2858.

FICHTNER, I., SLISOW, W., GILL, J., BECKER, M., ELBE, B., HILLEBRAND, T., and BIBBY, M. (2004). Anticancer drug response and expression of molecular markers in early-passage xenotransplanted colon carcinomas. Eur. J. Cancer 40, 298-307.

FURTH, P.A., SHAMAY, A., WALL, R.J., and HENNIGHAUSEN, L. (1992). Gene transfer into somatic tissue by jet injection. Anal. Biochem. 205, 365-368.

FURTH, P.A., KERR, D., and WALL, R. (1995). Gene transfer by jet injection into differentiated tissues of living animals and in organ culture. Mol. Biotechnol. 4, 121-127.

HACKETT, N.R., EL SAWY, T. , LEE, L.Y., SILVA, I., O'LEARY, J., ROSENGART, T.K., and CRYSTAL, R.G. (2000). Use of quantitative TaqMan real-time PCR to track the time-dependent distribution of gene transfer vectors in vivo. Mol. Ther. 2, 649-656.

HERWEIJER, H., ZHANG, G., SUBBOTIM, V.M., BUDKER, V., WILLIAMS, P., and WOLFF, J.A. (2001). Time course of gene expression after plasmid DNA gene transfer to the liver. J. Gene Med. 3, 280-291.

KAWASE, A., NOMURA, T., YASUDA, K., KOBAYASHI, N., HASHIDA, N., and TAKAKURA, Y. (2003). Disposition and gene expression characteristics in solid tumors and skeletal muscle after direct injection of naked plasmid DNA in mice. J. Pharmacol. Sci. 92, 1295-1304.

LI, S., and HUANG, L. (2000). Nonviral gene therapy: The promises and challenges. Gene Ther. 7, 31-34.

LIU, F., and HUANG, L. (2002). Development of non-viral vectors for systemic gene delivery. J. Control. Release 78, 259-266.

MARUYAMA, H., HIGUCHI, N., NISHIKAWA, Y., KAMEDA, S., IINO, N., KAZAMA, J.J., TAKAHASHI, N., SUGAWA, M., HANAWA, H., TADA, N., MIYAZAKI, J., and GEJYO, F. (2002). High-level expression of naked DNA delivered to rat liver via tail vein injection. J. Gene Med. 4, 333-341.

NIIDOME, T., and HUANG, L. (2002). Gene therapy progress and prospects: Nonviral vectors. Gene Ther. 9, 1647-1652.

PARKER, S.E., BORRELLINI, F., WENK, M.L., HOBART, P., HOFFMAN, S., HEDSTROM, R., LE, T., and NORMAN, J.A. (1999). Plasmid DNA malaria vaccine: Tissue distribution and safety studies in mice and rabbits. Hum. Gene Ther. 10, 741-758.

PILLING, A.M., HARMANN, R.M., JONES, S.A., MCCORMACK, N.A., LAVENDER, D., and HAWORTH, R. (2002). The assessment of local tolerance, acute toxicity, and DNA biodistribution follow- 
ing particle-mediated delivery of a DNA vaccine to minipigs. Toxicol. Pathol. 30, 298-305.

POUTON, C.W., and SEYMOUR, L.W. (2001). Key issues in non-viral gene delivery. Adv. Drug Deliv. Rev. 46, 187-203.

REN, S., LI, M., SMITH, J.M., DETOLLA, L.J., and FURTH, P.A. (2002). Low-volume jet injection for intradermal immunization in rabbits. BMC Biotechnol. 2, 10.

ROSE, A.C., GODDARD, C.A., COLLEDGE, W.H., CHENG, S.H., GILL, D.R., and HYDE, S.C. (2002). Optimisation of real-time quantitative RT-PCR for the evaluation of non-viral mediated gene transfer to the airways. Gene Ther. 9, 1312-1320.

SOMIARI, S., GLASSPOOL-MALONE, J., DRABICK, J.J., GILBERT, R.A., HELLER, R., JAROSZEWSKI, M.J., and MALONE, R.W. (2000). Theory and in vivo application of electroporative gene delivery. Mol. Ther. 2, 178-187.

WALTHER, W., and STEIN, U. (2000). Viral vectors for gene transfer: A review of their use in the treatment of human diseases. Drugs 60, 249-271.

WALTHER, W., STEIN, U., FICHTNER, I, MALCHEREK, L., LEMM, M., and SCHLAG, P.M. (2001). Non-viral in vivo gene delivery into tumors using a novel low volume jet-injection technology. Gene Ther. 8, 173-180.

WALTHER, W., STEIN, U., FICHTNER, I., VOSS, C., SCHMIDT, T., SCHLEEF, M., NELLESSEN, T., and SCHLAG, P.M. (2002). Intratumoral low volume jet-injection for efficient nonviral gene transfer. Mol. Biotechnol. 2, 105-115.
WALTHER, W., STEIN, U., FICHTNER, I., and SCHLAG, P.M. (2004). Low-volume jet-injection for efficient in vivo gene transfer. Mol. Biotechnol. 28, 121-128.

WALTHER W., STEIN, U., SIEGEL, R., FICHTNER, I., and SCHLAG, P.M. (2005). Use of the nuclease aurintricarboxylic acid (ATA) for improved non-viral intratumoral in vivo gene transfer by jet-injection. J. Gene Med. 7, 477-485.

ZHANG, G., VARGO, D., BUDKER, V., ARMSTRONG, N., KNECHTLE, S., and WOLFF, J.A. (1997). Expression of naked plasmid DNA injected into the afferent and efferent vessels of rodent and dog livers. Hum. Gene Ther. 8, 1763-1772.

\section{Address reprint requests to: \\ Dr. Wolfgang Walther Max Delbrück Center for Molecular Medicine Robert Rössle Strasse 10 13092 Berlin, Germany}

E-mail:wowalt@mdc-berlin.de

Received for publication March 13, 2006; accepted after revision March 30, 2006.

Published online: May 2, 2006. 